\title{
Diplomatic Channels and Chinese Whispers: Reception and Transformation of the Moscow Uprising of 1648 in Sweden and France
}

\author{
Malte Griesse
}

The Moscow uprising of 1648 took place almost simultaneously with innumerable other large-scale revolts throughout Europe and civil wars further afield. Contemporaries were well aware of this wider, simultaneous social upheaval and they drew parallels between events in countries with diverging political orders. They sought explanations of these phenomena, which they often attributed to common causes. Adler Salvius, one of the Swedish diplomats at the Westphalian Peace Congress, wrote:

It seems to be a great miracle that in the whole world people talk about revolts of the people against their sovereigns, for instance in France, Germany, Poland, Muscovy, Turkey ... If this has to be explained by a certain disposition of the stars or by something like a general agreement of the people against their bad governors: God alone can know it. ${ }^{1}$

The Dutch jack-of-all-trades Lieuwe van Aitzema, who worked as diplomat for the Hanseatic seaports as well as for the Dutch Republic and who spied for several other leading governments, composed an immense encyclopaedic multivolume work on (contemporary) 'state affairs' (Saken van Staet). The Moscow uprising does not loom large, but a few columns are dedicated to the events, which are compared with the Naples revolt under the leadership of Masaniello one year earlier (in 1647), mainly on the grounds of their 'popular' character. ${ }^{2}$

On the other hand, the prolific Venetian historians of contemporaneity, many of them members of the Academia degli Incogniti, did not say a word in their equally monumental works about what was going on in Muscovy.

1 Quoted from Georges Livet, La guerre de trente ans, 2nd ed. (Paris: Presses Universitaires de France, 1966), p. 121.

2 Lieuwe van Aitzema, Saken van staet en oorlogh, in, ende omtrent de Vereenigde Nederlanden, beginnende met het jaer 1645, ende eyndigende met het jaer 1656, vol. 3 (Graven-Haghe: Johan Veely, 1669), pp. 229-233. 
Maiolino Bisaccioni, for instance, had worked as a diplomat for several Italian courts, among them the papal court in Rome. In his History of Civil war of our times (1652) he deals with the revolts in England, Catalonia, Portugal, Palermo, Naples, Fermo, Poland (i.e. Ukraine), France and Turkey - and in a later edition (1655) he updates his narrative not only with regard to still continuing revolts, such as those in England and Ukraine, but even adds accounts of more recent events in Moldavia and Switzerland (1653). ${ }^{3}$ But the Moscow uprising of 1648 does not show up here. This is even more noteworthy since only three years before his first edition of the History, Bisaccioni had written a novelistic biography of (false) Tsar Dmitrii, one of the principal protagonists of the Time of Troubles, i.e. the civil war that had shaken the Muscovite Empire at the beginning of the seventeenth century. ${ }^{4}$ In the account of Poland in his History, he also highlights diplomatic and military enmeshments with Muscovy that sparked the Russo-Polish War of 1654-67 and would constitute a major ingredient of the Second Northern War (1655-1660). Muscovy was definitely on Bisaccioni's radar, but apparently he did not even know about the 1648 uprising that would have fitted perfectly into his panorama of contemporary civil wars and revolts.

Since the same is true for the other Italian writers of contemporary history, this illustrates that intelligence on Muscovite internal affairs was in the first place spread through the Northern routes of the Baltic Sea, where the adjacent countries entertained ongoing commercial and occasional diplomatic relations with Moscow. For the highly urbanised centres of Southern Europe the country was interesting primarily as a potential adversary of their own dangerous neighbour, the Ottoman Empire, but was also of interest on the rare occasions when religious dissensions stirred papal hopes that Russia might return to the fold (which was the case, for instance, in the time of Tsar Dmitrii, who was supposed to be crypto-Catholic). Muscovy was associated with the 'Northern' countries - the concept of the 'East' was yet to be born. Therefore, the spread of news and rumours concerning the Muscovite uprising, which I will dwell on in this article, is essentially a phenomenon of the Northern hemisphere, especially of the Baltic and the North Sea rim. Whereas accounts transmitted orally can only be retraced indirectly, the written reports examined here include both arcane and public communication.

3 Maiolino Bisaccioni, Historia delle guerre civili di questi ultimi tempi, 4th ed. (Venice: Storti, 1655).

4 Maiolino Bisaccioni, Il Demetrio moscovita: historia tragica, In questa ultima impressione corretta, accresciuta, et aggiuntaui la seconda parte (Venice: Viest, 1649). 
Both are part of what I call 'Chinese whispers', drawing to some extent on Albrecht Koschorke's narratology. According to the German literary scholar, all narration resembles Chinese whispers, but this does not lead to final messages that are 'crazier' than those first transmitted; on the contrary, the "thinning and adaptation of narrative material" leads back to "well-known narrative patterns". Narrating would be "a filter rather than a means of conveyance. ... Also an add-on can render the account more efficient, as long as it completes an established schema". The formation of such schemas is "based on three principal procedures: ellipsis, adjustment, completion". ${ }^{5}$ However, I am not aiming at narration as such, but apart from the signifier (i.e. the narration) I am interested in both its relationship to the signified (i.e. the historical/contemporaneous event referred to) and to the (cultural, political, social) context that contributes to a reframing of this relationship between signifier and signified and thus introduces new implicit references, be they real or potential, present or impending, perceived or expected, hoped for or apprehended. No doubt, retelling is a filter: it can definitely distort a message with regard to the depicted event - and we will see to what extent it did so in the case of the Muscovite uprising. But the emerging narrations have also to be read against the background of both (1) the context in which the commentator finds himself, and (2) the commentator's assumptions about the contexts in which his recipients find themselves. These multiple contexts are the frames that attribute meaning to the narration; and the longer the chain of 'whispers' becomes the greater is the variety of real or anticipated contexts. Since the whispers do not stop at state borders, we have to deal with extremely complicated processes of translation across borders of political cultures.

The importance of implicit meaning, i.e. of meaning borne by reference to recipients' contexts, is considerably increased by early modern governments' policies of damnatio memoriae with regard to domestic revolt. Rather than claiming interpretative predominance, after successful repression (or abating) of a revolt the authorities tried to silence and taboo the events. It was therefore much easier to discuss revolts abroad than to speak about an uprising at home. Foreign revolts could thus also serve as a projection surface for implicitly discussing delicate domestic issues. Misunderstandings and distortions of the original events, which are normally deplored by historians, are particularly interesting for my purpose, since they often show strikingly how events

5 Albrecht Koschorke, Wahrheit und Erfindung: Grundzüge einer allgemeinen Erzähltheorie (Frankfurt am Main: S. Fischer, 2012), p. 32. 
were translated into a new context and thereby generated new meanings. Cross-border reports therefore act as bridges between described and describing political cultures.

In the following I will retrace a loose chain of reports and rumours that leads me from the accounts of foreign residents in Moscow to Sweden and, via the French ambassador in Stockholm, to Paris where the Gazette de France reports on the Muscovite events in October. I thus focus on the accounts that remain close to the events in chronological terms.

\section{Reporting the Extraordinary in a Time of Crisis: Foreigners as Eyewitnesses}

Even though the accounts written by Swedish residents in Moscow of the 1648 uprising were not published, in sum Sweden was the most important communicative hub for the international diffusion of information about the events. Apart from the official resident's very substantial and regular diplomatic letters to the Swedish government, other accounts specifically dedicated to the events have been found in the Stockholm state archives. ${ }^{6}$ In addition, one anonymous Dutch eyewitness report has survived and been published in Leyden and Amsterdam (of which manuscript translations into English and French have been discovered), ${ }^{7}$ and Adam Olearius supplemented the second edition of his monumental travelogue on Muscovy and Persia with a second-hand

6 See especially the anonymous account in German found by Forsten and published by Sergei Fedorovich Platonov, 'Novyi istochnik dlia istorii moskovskikh volnenii 1648 g., Chteniia v Imperatorskom obshchestve istorii i drevnostei rossiiskikh pri Moskovskom universitete (ChIOIDR), 164 (1893), Section III, pp. 1-19. In addition, Peter Loofeldt's account is of interest. Although he never resided in Muscovy, his report was apparently written with more hindsight than the others that have been examined.

7 Waerachtighe historie ende beschryvinghe, van het schrickelijck tumult ende oproer in der Moscou, op den 2 Iunij 1648. Ontstaen uyt de groote ende onverdragelijcke schattinghen, tollen ende contributien der ghemeynte opgeleyt. Alles partilculierlijck door een aensienelijck ende geloofwaerdigh persoon, die aldaer tegenwoordigh is gheweest, beschreven, ende hier te lande tot Amsterdam, aen seker sijnen vrient, overghesonden. Wt het origineel gecopyeert, ghedruckt tot Amsterdam ... Anno 1648 (Amsterdam, 1648). The English translation found in the Bodleian Library has been published by Leo Loewenson, 'The Moscow Rising of 1648', Slavonic and East European Review (SEER), 27 (1948), pp. 146-156, whereas the French version, probably translated by Denis Godefroy, the French court historiographer, has not yet attracted attention within the scientific community. 
description of the uprising. ${ }^{8}$ All existing foreigners' accounts seem to originate from diplomats or diplomat-like correspondents.

The only eyewitness-author, though, whose name we know and whose consecutive reports on the events have been preserved, is Karl Pommerening. In 1647 he succeeded Peter Krusebjörn as Swedish resident in Moscow. His letters are directly addressed to Queen Christina - and later occasionally also to her secretary. He reports on the Moscow uprising of 1648 at great length. The revolt broke out on 1 June, but Pommerening's first dispatch with several successive accounts was only sent in July, more than a month later. The delay was due to the chaos and the breakdown of ordinary lines of communication, as he affirms in the first letter. But he does not limit himself to depicting the most spectacular and bloody events at the beginning of the uprising in early June; he also relates the succeeding waves and aftershocks in his following letters. His depictions of the events are remarkably balanced, even though he himself had become a victim of the turmoil. His house in the foreign suburb was burned down by the big fire that destroyed more than half of the city.

Apparently this experience did not impair his rather comprehensive attitude towards the insurgent populace. He does not speak of the assembled 'mob', as is done in other accounts, but of the 'commoners' (gemene mannen, or related terms). Indeed, the foreign eyewitnesses seem to be more or less unanimous in their empathy with the people. They consider well-founded their complaints about excessive taxes and in particular the ruling elite's peculations, cruelty, abuse of power and greed. They even tend to explain xenophobic tendencies, from which they potentially suffer personally, by the foreigners' privileged status, especially in trade. ${ }^{9}$ Even though the term is not used

8 Among his correspondents were the physicians W. Sybelist, H. Gramann and J. Belau, as well as the merchants Peter Marselis and D. Ruts. See Uwe Liszkowski, 'Adam Olearius' Beschreibung des Moskauer Reiches', in Mechthild Keller, Ursula Dettbarn and Karl-Heinz Korn (eds.), Russen und Rußland aus deutscher Sicht: 9.-17.Jahrhundert (München: Fink, 1985), pp. 223-246 (238); Stefan Roller-Aßfalg, 'Der Moskauer Aufstand von 1648', in Heinz-Dietrich Löwe (ed.), Volksaufstände in Rußland: Von der Zeit der Wirren bis zur 'Grünen Revolution' gegen die Sowjetherrschaft, (Wiesbaden: Harrassowitz, 2006), pp. 69-104 (73). Liszkowski also writes about newspaper reports as a source for Olearius' account, but he does not specify which newspapers he refers to.

9 He related that the Dutch ambassador hoped to profit by the chaos and obtain even more for his merchants, who had the furthest-reaching privileges and were about to crowd out the English from the Russian markets. But as Pommerening states, in the course of the revolt the Russian merchants tried hard to force the Dutch out of Moscow altogether. K.V. Bazilevich, 
and the insurgents' violence not openly justified, what shines through is the idea of a ius resistendi.

Instead of blaming the insurgents for the fire, Pommerening accuses Boris Mozorov, Tsar Aleksei's favourite and the actual regent, who "is equally hated by the lower and the upper sorts". ${ }^{10}$ The commoners consider Morozov to be the main culprit and 'traitor' and call for his head. For that reason Morozov would have instructed his "servants to set fire to the city simultaneously at different places", in order to divert the insurgents' attention and bring their rage to a halt to allow for his escape in the ensuing chaos. Morozov would thereby have put up deliberately with thousands of deaths, as well as with invaluable material losses. This pro-insurgent version of Morozov as incendiary can also be found in the anonymous Swedish account. ${ }^{11}$ None of the foreigners' records assumes that the fire was an accident, as it is taken for granted (later) in Russian chronicles. ${ }^{12}$

According to Pommerening's reports, even those written well before the actual uprising, Tsar Aleksei had remained emotionally dependent on Morozov, his former tutor. Shortly after Tsar Aleksei's succession to the throne and Morozov's promotion, Pommerening's predecessor Krusebjörn had anticipated far-reaching changes:

A few days ago Prince F.I. Scheremetieff [Sheremet'ev], who was closest to His Majesty's blessed father in his lifetime and whose councils were decisive for the direction of Russia's most important affairs, has voluntarily renounced from his high office. This will probably entail significant changes in government, since Boris Morozoff ..., a firm and stiff man, who sticks closely to the old Russian customs and morals, has taken his place. $^{13}$

The fact that the new tsar did not generally attend government meetings made Morozov's position even stronger.

Gorodskie vosstaniia v Moskovskom gosudarstve XVII v. Sbornik dokumentov (Moscow: Gosudarstvennaia publichnaia istoricheskaia biblioteka Rossii, 2003), p. 39.

10 Pommerening to Queen Christina, 7 July 1648 , see Bazilevich, Gorodskie vosstaniia.

11 Platonov, 'Novyi istochnik', pp. 16-17.

12 Loewenson, 'The Moscow Rising of 1648', pp. 154-155.

13 Krusebjorn to Queen Christina, 2 February 1646, see G.V. Forsten, 'Snosheniia Shvetsii s Rossiei v tsarstvovanie Khristiny', Zhurnal Ministerstva narodnogo prosveshcheniia, 275 (1891), pp. 348-375 (368-369). 
As Pommerening affirms, Morozov exploited his overwhelming power in order to plant his clients in all positions of influence and the officials of his network systematically abused their offices to enrich themselves at the expense of the broader population. The judge of the Zemskii Prikaz (the Office of the country) Leontii Pleshcheev is said to have hired criminals "for imputing crimes to honest and rich people", in order to except them from their money. And indeed, before his promotion to the central office under Tsar Aleksei, as voevode (governor) of Vologda under Tsar Mikhail, Pleshcheev had been accused of theft and was exiled to Siberia. Pommerening does not evoke Pleshcheev's past but, curiously enough, the anonymous Swedish account construes a precedent of arson precisely in this context:

It is said about this Pleschoeou [Pleshcheev] that about 1o years ago, out of greed and thirst for booty, as well as in order to better maintain his own servants, he had set a blaze in the city of Moscow. Since several hundreds of houses had burned down, he was condemned to be beheaded, but due to a mighty intercession and thanks to His Majesty's outstanding act of grace, his life was spared and he was sent with his family to Siberia. ${ }^{14}$

Now, in 1648, together with his brother-in-law Petr Tikhonovich Trakhaniotov, head of the Canonn Office [Pushkarskii Prikaz], and with the 'Chancellor' Nazarii Chistyi, a wealthy merchant [gost], who had become a high-ranking bureaucrat (dumnyi d'iak of the ambassadorial office), Pleshcheev was held responsible by the insurgents for the exorbitant increase in taxes.

The foreign observers are sensitive to the collective dynamism of the revolt and to the formation of inter-social alliances that gave the movement its threatening impact. At the same time they attribute crucial significance to the tsar's behaviour and to his role - and failures - as the most important communicative hub. It becomes clear that for the protesting people he was the main addressee. For this reason, his shortcomings in terms of mediation and communication are singled out as important accelerators of the revolt.

When on June 1st the grand prince was coming from his Troitskii procession to Moscow, the commoners complained, as they had done formerly, about the falsehood and coercion they had been subjected to, which can be seen from the enclosed supplication.

14 Sergei Fedorovich Platonov, 'Moskovskie volneniia 1648 goda', Zhurnal Ministerstva narodnogo prosveshcheniia, 267 (1888), p. 15. 
He explicitly states: "as they had done formerly". Thus he does not yet consider the assembled crowd to be insurrectional, because the people make use of nothing more than their right of petition. Pommerening regards the tsar's reaction, or the reaction of his entourage, as the actual trigger of the revolt:

\begin{abstract}
And since His Tsar's Majesty did not want to receive the supplication himself and the commoners were instead beaten with knouts, they started to throw stones and to descend on a series of notable boyars; 15 or 16 people who followed the Tsar with the supplication to the Kremlin were thrown into the tower.
\end{abstract}

The general picture is quite clear: the peacefully assembled people want to bring their complaints directly to the tsar, but they are relegated to those whose despotism they are decrying. Pommerening states that the tsar does not want to hear their case. In the Leyden Brochure, it is the 'boyar' entourage that screens the tsar from sight. The contemporaneous English manuscript translation of the pamphlet reads:

The Bojates [i.e. boyars], environing his imperiall Majestie, got these petitions, tore $\mathrm{y}^{\mathrm{e}}$ same not onely into pieces, flung the pieces into the petitioners faces, rayling at them mightily, and caused them to be cruelly beaten by their chalopps [kholopy] or slaves, and imprisoned a great many of them. ${ }^{15}$

In both accounts the people still remain peaceful. According to Pommerening, violence is only started by the guards, who are instructed to lash out at the assembled petitioners. This finally provoked violence on the part of some petitioners. But only a few let themselves be driven to shy stones against boyar officials. Therefore the guard has no difficulty in dispersing the crowd and arresting the alleged ringleaders.

But the next day a crowd reassembled at the occasion of the tsar's second Pentecost procession within the city, where it was harder to screen him from sight: "Again the commoners followed him and solicited the liberation of those arrested the previous day (which was immediately granted) and the surrender of those who suck their blood and torment the innocent". 16 The 'bloodsuckers' are clearly named, among them Morozov. Tsar Aleksei does not want to aban-

15 Loewenson, 'The Moscow Rising of 1648', p. 153.

16 Pommerening to Queen Christina, letter dated 6 July 1648. Bazilevich, Gorodskie vosstaniia, p. 36 . 
don his favourite, and his favourite does not want to abandon his clients. Again the tsar tries initially to send ahead others to negotiate with the crowd, among them the Patriarch as the highest representative of the Orthodox Church. However, "the Patriarch's admonishments did not help, and not even the words of his Majesty himself were able to calm down the unrest", unless he would yield to their demands. People seem to have drawn their lessons from their reversal of the previous day. A considerable part of them intruded into the territory of the Kremlin, the very centre of power and

since in the meantime Morozov's servants beat some of the musketeers [i.e. the military guard], because they had not prevented the people from entering the Kremlin, the musketeers declared that they had only His Majesty the Tsar [i.e. only recognised him as authority], but no favourite, and that they didn't want to fight for the boyars against the people, but were ready to help [the people] to get rid of the boyars' coercion and falsehood. ${ }^{17}$

The military guard virtually defects to the petitioners and a new coalition takes shape, which changes the balance of power. The musketeers refuse obedience to the boyars, but explicitly declare their loyalty to the tsar. Aleksei could have commanded them to evacuate the Kremlin from the petitioners, but he would not dare to do so:

Then, in the presence of His Tsarist Majesty, they [the musketeers] joined the people to ravage and destroy Boris Morozov's house on the Kremlin territory; from there they went to chancellor Nazarii [Chistyi's] house who was already sick and after having been severely harassed was thrown down and killed: for a long time he lay bare on a dunghill. In the same manner they continued to destroy the houses of the above-mentioned persons, until on 3 June the huge fire spread everywhere. ${ }^{18}$

The Russian original of the petition is not preserved, probably because it was never handed over to the tsar even in the following days. Pommerening is quite clear about its non-acceptance having largely contributed to provoking the shift from peaceful assembly to large-scale crowd violence. Most likely several

\footnotetext{
17 Ibid., pp. $36-37$.

18 Ibid., p. 37. This defenestration certainly reminded Swedish readers of the Prague events in 1618 that had triggered the Thirty Years' War. Throwing 'traitors' from towers, bridges or out of windows was a recurrent ritual of execution staged by insurgents in Russia.
} 
petitions were circulating during these days: different copies or even different versions. The document enclosed with the resident's correspondence is the only surviving 'copy'. The effort he took to have translated the extensive document shows to what extent the Swedish government was interested both in the insurgents' complaints and their ways of voicing them.

According to Pommerening the petition comes from the 'gemene mannen', i.e. the 'commoners' as opposed to the privileged estates. ${ }^{19}$ But towards the end of the document, the authors say they represent "the simple Muscovite gentry, urban service people, gosti (wealthy merchants engaging in long-distance trade) and merchants (with lower-scale businesses), [as well as] the upper and lower ranks of Moscow".

The musketeers' declaration of undamaged loyalty to the tsar, combined with a de facto prescription regarding how the monarch should behave, is substantiated by the petition. To be sure, the biggest part of the document is devoted to a depiction of outrageous abuses, embezzlement, cruelty and general arbitrariness of corrupt Muscovite officials, in particular those of the Morozov clan. At some points resentment shines through against those social climbers, who made it into the highest bureaucracy and managed by means of unlawful exactions, excessive imposts and bribes "to amass piles of riches and build themselves houses that do not befit their rank: in the times of former grand princes this was not customary". ${ }^{20}$

Such passages are quoted by historians as proof of the people's traditionalism and resistance against a modernising state and the formation of a modern bureaucracy based on merit instead of birth. ${ }^{21}$ But social agents engaging in collective protest have to justify their actions along the lines of generally accepted, common good-oriented principles. Indeed, by referring to the limitations imposed by ranks they do appeal to the patriarchal values of an estate-based society that is supposed to assure social peace. But this is only a subordinate element of their reasoning. The main thrust of their argument

19 In Muscovite society he refers to the chernye, the tax-paying population inside (posadskie liudi) and outside the city walls.

20

P.P. Smirnov, 'Chelobitnye dvorian i detei boiarskikh vsekh gorodov v pervoi polovine XVII veka', Chteniia v Imperatorskom obshchestve istorii i drevnostei rossiiskikh pri Moskovskom universitete (ChIOIDR), 3 (1915), pp. 1-73 (62).

21 The most interesting and balanced interpretation of the uprising as resistance against the establishment of a new bureaucracy can be found in Valerie Ann Kivelson, 'The Devil Stole His Mind: The Tsar and the 1648 Moscow Uprising', The American Historical Review, 98:3 (1993), pp. 733-756. Cf. also Hans-Joachim Torke, Die staatsbedingte Gesellschaft im Moskauer Reich: Zar und Zemlja in der altrussischen Herrschaftsverfassung 1613-1689 (Leiden: Brill, 1974), pp. 218-244; Roller-Aßfalg, 'Der Moskauer Aufstand von 1648'. 
is to deny the accused bureaucrats their alleged merit. Instead of serving the common good they pursue nothing but selfish interests and pad their pockets by plundering the subjects and the tsar's treasury, so that many regions of the country already 'lie barren'. Therefore the tsar is asked to take the reins of government himself and to replace his corrupt officials by deserving people, who are really devoted to the common good. Thus meritocracy is not repudiated, but vehemently called for.

It is a widespread pattern in early modern protest movements, not only in Russia, to blame the 'evil councillors' while hailing the monarch's benevolence and benignity. But the petition does not stop there. The tsar himself is clearly informed of his limits:

It has come to the point that they [the corrupt officials] have set His Tsarist Majesty against the people - and the people against His Majesty. And due to these injustices the population of the entire Muscovite State and its border regions are put into a state of unsteadiness, as a consequence of which a storm will be arising in the city of Moscow and in many other places, in towns and districts, if Your Majesty the Tsar will continue to tolerate and pardon the ever increasing oppression of the poor and leave this gang of crooks unpunished, which only makes them feel safer in their practice of bribery and embezzlement. ${ }^{22}$

Concerning the impending outbreak of unrest in numerous Russian cities, this passage turns out to be prophetic - or can be read as a direct threat. The tsar is commanded to "remember that you, Sovereign, were called to the throne by God Himself, not by your own will". If he does not take to heart "the humble supplication of Your slaves and orphans", he should keep in mind "that God's wrath, which has formerly been spilled on the Muscovite state as a punishment for such lawlessness, is supposed to attain it again". ${ }^{23}$ This is an unambiguous allusion to the Time of Troubles (Smutnoe vremia), the great and traumatic civil war at the beginning of the seventeenth century, in which numerous pretenders were claiming the throne and tsars were dethroned almost in series, which provoked far-reaching Polish and Swedish intervention and shook the country to its very foundations. The events were also part of the recent history of Sweden and Pommerening can count on the understanding of his readers.

In fact, it was with the election of Mikhail Romanov as new tsar in 1613 that the civil war gradually came to an end and that the Romanov dynasty was in-

22 Smirnov, 'Chelobitnye dvorian', pp. 62-63.

23 Ibid., p. 63. 
stalled. This at least is how it looks with historical hindsight since, after Tsar Mikhail's death in 1645, the 16-year old Aleksei succeeded his father smoothly and without any complications. But the petitioners suggest that the Romanovs lack the unquestioned divine legitimacy of the former Rurik dynasty. In a subclause they boldly affirm that: "Your Majesty the Tsar - as well as your defunct father, after the complete destruction of the Muscovite state by evil men - has been installed and elected sovereign and grand prince by God and the entire people". ${ }^{24}$ In combination with the insurgents' deeds and behaviour towards the sovereign this implies that if Tsar Aleksei does not fulfill his responsibilities towards the entire country and the common good, the people can withdraw their consent and take matters into their own hands as is suggested at the end of the petition:

You shall have all the unjust judges extirpated and the ignorant disposed and have them replaced by suitable people, who are able to answer for their judgments and their service before God and before Your Majesty. And if [you can] not [do that], then Your Tsarist Majesty shall let the commoners themselves nominate all service men and judges by their own means and to select those, who will guide them between custom and justice and who can protect them against violence of the mighty. ${ }^{25}$

Even though the petitioners call themselves the tsar's "slaves and orphans" (the customary manner of addressing the tsar), their propositions, claims and suggestions are hard to reconcile with a 'naïve monarchism' of a servile people 'born to slavery.' ${ }^{26}$ The supplication concludes with what sounds almost ironic: the people's agency is supposed to relieve both the tsar and the boyars "from all sorts of excessive work". The tsar would be able "to govern his tsarist crown in complete tranquillity" and the boyars could "more conveniently manage their domestic affairs". ${ }^{27}$ What this 'tsarist cause' should be is not specified: foreign

\footnotetext{
24 Ibid., p. 62.

25 Ibid., p. 64.

26 The concept of 'naïve monarchism' stems from the Slavophil tradition of the nineteenth century. See a discussion of the concept in Daniel Field, Rebels in the Name of the Tsar (Boston: Houghton Mifflin, 1976), pp. 1-27. The concept of inborn slavery as the counterpart of autocracy is vehemently defended by Marshall T. Poe, 'A People Born to Slavery': Russia in Early Modern European Ethnography, 1476-1748 (Ithaca, NY: Cornell University Press, 2000).

27 Smirnov, 'Chelobitnye dvorian', pp. 64-65.
} 
policy or rather hunting parties and similar amusements, which Tsar Aleksei was known to prefer over government affairs. ${ }^{28}$

Against the background of what was simultaneously going on elsewhere, Pommerening and his readers in Sweden could have drawn numerous parallels, for instance to England, where King Charles I had been divested of the army and most government affairs and thus temporarily been reduced to his 'private body' as it was argued by the ideologues of the English Parliament, who were drawing on medieval political theology in order to justify their takeover of the functions of the king's 'political body'. ${ }^{29}$ (Charles' execution still lay ahead.) The Muscovite petitioners did not use the language of the 'body politic', but in the foreigners' accounts their arguments and deeds headed in a similar direction.

The tsar's youth, inability or unwillingness to govern on his own, and his ongoing ties to his tutor, who was at the same time the most influential statesman, invite comparisons with Sweden, where the authorities were particularly afraid of an impending uprising. Both sovereigns, Aleksei and Christina, had only recently reached majority - and royal minority or weakness had been identified by numerous observers as common triggers of political violence and revolts. ${ }^{30}$ In both cases, the former tutors to the dauphin pulled the strings of politics. Morozov owed his predominant position to Aleksei's succession to the throne; Oxenstierna had obtained his overwhelming power much earlier under Christina's father Gustav Adolf. Both of them were efficient networkers, but due to the different political system with a regular representation of the four Estates in the Swedish Diet, Oxenstierna had to rely on persuasion and was at the same time an extremely skillful public orator, as can be seen from preserved protocols of the Diet. To be sure, Christina was much more independent in emotional and intellectual terms and occasionally also tried to emancipate herself from Oxenstierna on a political level. But at the same time she was known to be rather averse to the work of government and similarly prone to sumptuous balls as Aleksei was prone to hunting parties.

When Pommerening depicts the rapid emergence of a broad coalition between diverse social strata against the governing elite in Muscovy that lead

28 Cf. Krusebjörn's letter from 14 October 1645, Forsten, 'Snosheniia Shvetsii s Rossiei', p. 368.

29 On the king's two bodies, see Ernst H. Kantorowicz, The King's Two Bodies: A Study in Mediaeval Political Theology (Princeton: Princeton University Press, 1981).

3o For numerous examples see Yves-Marie Bercé, 'Political Vacuum and Interregnum in Early Modern Unrest', in Malte Griesse (ed.), From Mutual Observation to Propaganda War. Premodern Revolts in Their Transnational Representations (Bielefeld: Transcript, 2014), pp. 81-91. 
not only to peaceful petitions, but eventually to an enormous orgy of violence, this should have reminded Swedish readers of the broad cross-Estates opposition that was forming against the Oxenstierna clan in their own country. Pommerening and the other observers highlight the monarch's failure to fulfill his role as communicative hub standing above political factions. This is more or less clearly singled out as the decisive trigger for the outbreak of large-scale violence. At the same time, the Swedish government received very similar analyses from other foreign trouble spots, most explicitly from their ambassador to the French court, Schering Rosenhane, who commented from Paris on the unfolding Fronde. While criticising Cardinal Mazarin for his failure properly to communicate his government policy and thereby aggravating social and political tensions, the ambassador posed as sort of a consultant to other governments - in the first place the Swedish one - which should avoid similar errors. ${ }^{31}$ Taking into account the Swedish authorities' notorious fear of revolts, its general willingness to learn from foreign examples, its proneness to seek reconciliation via communication, balancing of interests and even concessions, as well as of the simultaneous reception of Rosenhane's reports from France, the Swedish residents' analyses of the Moscow events fell on fertile ground in the Queen's council. ${ }^{32}$

\section{A Large-scale Boyar Conspiracy? Rumours of the Moscow Events on Their Way to Paris}

The news from Moscow was highly valued in Sweden, but due to blocked lines of communication, letters from Moscow took a long time to arrive there. In the meantime, the Swedish government was limited to rumours, mainly those spread across the border. This was the situation in August, when the French ambassador to the Swedish court Pierre Chanut reported to Cardinal Mazarin, his master in Paris, what he had picked up in Stockholm about Muscovite

31 On Rosenhane's reports and the Latin publication of his Observations on the Fronde, see Erik Thomson, 'Le travail du diplomate et la diffusion des idées politiques à l'époque moderne: la Fronde vue par le résident suédois Schering Rosenhane (1648-1649)', Histoire, économie et société, 29:1 (2010), pp. 13-23; Malte Griesse, 'Swedish Observations on the Fronde: Schering Rosenhane as Ambassador to the French Court', in Malte Griesse, Monika Barget and David de Boer (eds.), Ink and Blood: Writing Rebellion in Early Modern Diplomacy (Ashgate-Routledge, forthcoming).

32 On Swedish fear of revolts see Miriam Rönnqvist, 'Fighting Fires and Weathering Storms: Fear of Peasant Revolt and Communication of Revolts in Early Modern Sweden', Revue d'Histoire Nordique/Nordic Historical Review, 18 (2014), pp. 125-145. 
events. Chanut was very close to Queen Christina and often managed to obtain arcane information from the Swedish court. ${ }^{33}$ But in this case he had no clue about Pommerening's reports.

His account of Muscovy follows a report on Swedish-Polish peace negotiations. He introduces it by stating that contradictory versions of "the troubles of the Muscovite court" were circulating in Sweden and he recapitulates "a big relation (grande relation) that came from Novgorod and Pskov" about what sounds like a fantastic plot involving the mightiest boyars conspiring in order to kill the Grand prince. They wanted to break the Empire apart into governments and principalities and divide them among themselves. The ensemble of these principalities was to be subjected to an eligible chief - in the manner of the German Empire. In order to assure that these huge changes in government would not be disturbed by foreign interventions, the conspirators would have secretly negotiated with the Crimean Tartars and promised them a big province on the Southern border in exchange for military help if it would be necessary. "Morosoph", the "premier minister" and brother-in-law (beau-frère) of the Grand prince, as well as the "chancellor Nazari" (by which he means Chistyi) would have been part of this plot. But the conspiracy would have been uncovered by a certain "Banaanoph", a relative of the Grand Prince and the Patriarch's son. The defector had regretted his participation in the huge treason and informed the Grand Prince, providing proof and the names of all involved conspirators. The tsar then invited these people into his palace under different pretexts and had them all killed and their corpses thrown to the dogs in the streets. The people [le peuple] would have watched this tragedy with great pleasure, because shortly before they had complained that the ministers were abusing their power, selling their 'services' for a lot of money and imposing more and more taxes on the population. Therefore, instead of showing pity and compassion in the face of this big slaughter of the seigneurs, the people did not even forgive their families, but pillaged their houses and set many of them on fire. At the same time, the Grand Prince had sent people to the provinces, in order to get hold of all the other culprits. "Chancellor Nazari" would have escaped the massacre, because he did not obey to the Grand Prince's order to come to the palace, but on the following day he would have poisoned himself. ${ }^{34}$

33 On Chanut's close relationship to Queen Christina, see Jean-François de Raymond, Pierre Chanut, ami de Descartes: un diplomate philosophe (Paris: Beauchesne, 1999).

34 Pierre Linage de Vauciennes, Memoires de ce qui s'est passé en Suède, et aux provinces voisines, depuis l'année 1645 jusques en l'année 1655; ensemble le demêlé de la Suède avec la Pologne, tirez des depesches de Monsieur Chanut, ambassadeur pour le roy en Suède, vol. 1 (Cologne: Pierre du Marteau, 1677), pp. 332-333. 
To be sure, Pommerening had not written a word about such a fancy conspiracy of the grandees against the tsar as being the cause of the uprising or even of large-scale retribution. The scenario of (thwarted) regicide rather recalls contemporaneous plays staged at the French and other courts. ${ }^{35}$ Chanut's fantastic scenario must, therefore, be seen as the result of "Chinese Whispers" and I will try to retrace the rumours, from which the story might have been pieced together. In the scenario, a central element stands out: the tsar is the active part; he immediately takes the initiative, when being informed about the assassination plans by the mysterious "Banaanoph", allegedly Patriarch Iosif's son and a relative of the tsar (of whom we do not know anything from reliable sources). The people are on the tsar's side, but they only take up his initiative. Having been continuously abused and exploited by the traitors, they gleefully welcome the tsar's revenge and top it by pillaging the culprits' houses. Apart from "Banaanoph" the names of the plotters correspond to those against whom the people (insurgents) actually did voice their grievances and petitioned to the tsar. Even the story of the escape is documented in a narration by Simon Azar'in, the cellarer of the Troitse-Sergiev monastery, according to which a "certain magnate" fled from Moscow to the monastery, where his presence would have offended the icon of Saint Sergei Radonezhskii, the founder of the monastery of the fourteenth century. ${ }^{36}$ The story does not refer to "chancellor Nazari" (Chistyi), though, but to Trakhaniotov. According to Azar'in and the eyewitness accounts from Moscow, Trakhaniotov did not commit suicide, but was caught, brought back to Moscow and executed in a popular ritual of punishment.

As in the insurgents' petition these "ministers" are enemies of the people, violators of the common good, and therefore also enemies of the tsar, who they screen from his subjects in order to shroud their own misdeeds. Altogether it is remarkable to what extent the scenario corresponds to popular representations of the events, especially those circulating outside the capital.

From Pommerening's accounts and especially from the petition he forwarded to the Swedish court in translation we have seen how the insurgents insisted upon acting in the name of the tsar, and how, in direct confrontation, they tried to push Tsar Aleksei to subscribe to their cause. The Moscow events resonated

35 From a total of 116 tragedies published in France between 1634 and 1651 Lise Michel has counted 18 , where the monarch is actually assassinated, and many others, where regicide is planned or announced in the course of the plot. Lise Michel, 'Régicide et dramaturgie dans la tragédie française, de La Mort de César de Scudéry (1636) à la Rosemonde de Baro (1651)', Littératures classiques, 67 (2008), pp. 115-129 (115).

$36 \quad$ Bazilevich, Gorodskie vosstaniia, pp. 88-91. 
throughout the whole country, and in many provincial towns uprisings immediately followed the advent of rumours about the dramatic happenings in the capital. The authorities reacted in a similar way as those in many other European countries in case of domestic revolts: they tried to control rumours and punish the messengers. Bearers of 'false news' were considered insurgents and in several cases their tongues were cut off, the organs with which they had infringed the taboo and thereby offended the state. ${ }^{37}$

Chinese whispers modified the image of the events and often these modifications tended to approximate the desires and imaginaries of those who told and retold them. Dissatisfaction with taxes and corrupt officials was widespread throughout the country and the most obvious way to legitimise resistance was to act in the name of the tsar. And indeed, rumours from Moscow about the tsar's behaviour encouraged people in the provinces and helped them justify their insubordination against local and regional officials. This is clearly captured in Chanut's "grande relation", where the tsar "sends [his emissaries] to the provinces to seize the culprits". What else might ensue from such a rumour if not that the tsar needed (his people's) assistance?

In Pommerening's and other foreigners' accounts Tsar Aleksei looks helpless: he desperately tries to protect Morozov. However, in the end he must ban him from the capital 'forever' (in fact, Morozov would come back in less than two months). Together with the populace the musketeers pillage and destroy Morozov's, Pleshcheev's and other officials' houses - in the presence of the sovereign, who does not object to these 'punishments'. The enraged people are certainly persuaded to act with the tsar's approval, or perhaps even by his command. This and similar versions of the events were spread by the insurgents themselves. In their eyes, Morozov and the other officials were not only enemies of the people, but also traitors against the tsar, since they wanted to deprive him of his power in order to rule the country on their own, serving exclusively their excessive self-interests.

It is no mere coincidence that many of the juridical cases related to unseemly talk about the uprising involved dependents of Prince Dmitrii Mamstriukovich

37 See the case of Andrei Larionov, who was punished for spreading rumours and instigating a new revolt. The case is summarised in Sergei Vladimirovich Bakhrushin, 'Moskovskoe vosstanie 1648 g., in Nauchnye trudy 2. Stat'i po ékonomicheskoi, sotsial'noi, i politicheskoi istorii russkogo tsentralizovannogo gosudarstva XV-XVII vv. (Moskva: Izdatel'stvo Akademii nauk sssR, 1954), pp. 66-67. In early 1649 Pommerening also reported about the punishment of four gossipers who, while talking about the past events, anticipated a new uprising. "Two of them were beheaded, and two others had their tongues cut out..." Letter of 9 February 1649, Bazilevich, Gorodskie vosstaniia, p. 47. 
Cherkasskii and Prince Nikita Ivanovich Romanov (the tsar's father's cousin), the two boyars, who had been ousted from political key positions by Morozov and his clique and who hence led the most powerful anti-Morozov faction at court and came to re-occupy the leading offices during (the intermezzo of) Morozov's exile. ${ }^{38}$ As we can see from Pommerening's account, Tsar Aleksei, in his plight, finally relied on their popularity: they talked to the insurgents and largely contributed to soothe their anger, in combination with the tsar's own appearance before the people and his concessions. ${ }^{39}$

Persecution of the loose tongues only started after Morozov's restoration to office. However, even though some denunciators decried talks, in which the Princes Romanov and Cherkasskii should have appeared as instigators, they were never touched or reprimanded themselves. ${ }^{40}$ This would have been an extremely delicate issue, since they seemed to have considerable parts of public opinion on their side. Most likely the court faction assembled around the Princes played an active role in the dissemination of rumours that presented the tsar as the active part against the 'traitors'. ${ }^{41}$ The rumours accusing Morozov of Moscow's destruction, which corroborated the idea that he was a traitor to the tsar, are repeated not only in Swedish reports, but they even made their way into one (albeit exceptional) Russian account of the events, where the 'traitors' of the Morozov-clan are confronted with the protesting people as 'the community' (mir) and even 'the whole country' (vsia zemlia), i.e. as legal entities, that come to an agreement [dogovorilisia] with the tsar about punishments and banishments. ${ }^{42}$ In this account Morozov and Trakhaniotov have already been deposed from office and condemned to exile by the tsar, "wherever you, the mir, deem appropriate", when, "inspired by the devil [naucheniem d'iavol'skim], they sent out their people throughout Moscow and ordered them to burn down all Moscow". ${ }^{43}$ They are not said to have attempted to take the

38 Bakhrushin, 'Moskovskoe vosstanie 1648 g..

39 Bazilevich, Gorodskie vosstaniia, pp. 37-38.

40 Bakhrushin, 'Moskovskoe vosstanie 1648 g., pp. 66-67.

41 Kivelson, 'The Devil Stole His Mind', p. 740, mainly focuses on the anti-Morozov tendency of the rumours fostered by the Princes' faction. The two Princes' crucial role in disseminating rumours is also highlighted in the second- (or third?-) hand account by Peter Loofeldt, a Swedish diplomat working in the Swedish border towns, who had never been permitted access to Moscow. See Heinz E. Ellersieck, Russia under Aleksei Mikhailovich and Feodor Alekseevich, 1645-1682: The Scandinavian Sources (Unpublished Ph.D. diss., University of California, Los Angeles, 1955), p. 326.

42 The reference to elements of a contract concluded between tsar and people is in tune with the assumptions underlying the people's petition forwarded by Pommerening.

43 Bazilevich, Gorodskie vosstaniia, pp. 81-83. 
tsar's life as in Chanut's account, but the ingredients of conspiracy and treason are present - and even though Aleksei's attachment to his tutor is highlighted, the tsar appears as considerably more active than in the Swedish residents' and other foreigners' accounts. ${ }^{44}$

The tsar's activity and his alliance with the people against a gang of traitors, who have infiltrated and usurped government, are the major elements of the story that encouraged revolts in many other cities of the realm, often directed against officials in league with Morozov. In general, the three pillars (the tsar with people against Morozov-traitors) remained intact, since they corresponded to the expectations and interests of the insurgents in the provinces, who were also disaffected with their rulers. But in the process of oral transmission over long distances and through numerous intermediaries, the story built on these pillars could change considerably (as can be seen from the series of legal cases in the provinces). ${ }^{45}$ Both the tsar's commitment to Morozov and the constitutionalist vein in the confrontation between tsar and people (which play such a crucial role in foreign residents' reports and the petition, as well as in the quoted Russian account) seemed to disappear in the versions of the Moscow events as they were told and 'used' in political confrontations in the provinces. Since the tsar was not personally present, it was much easier than in Moscow to imagine him in unison with his people. This illustrates that limitations of, and eventually even legal resistance to, the tsar's power (and autocracy) were indeed part of Muscovite political repertoire, but that they were downplayed as far as possible in favour of the image of the 'good tsar', who incarnated the common good and the will of his people. ${ }^{46}$

Curiously, this constitutionalist dimension reemerges in Chanut's account, but acquires a completely different meaning, when attributed to Morozov and his clique. They allegedly want to overthrow autocracy in order to establish a new political order as it is known 'from the Holy Roman Empire'. Since Muscovy was often represented as autocracy, ${ }^{47}$ these Swedish rumours associate constitutionalist aspirations with treason. But the version of a political overthrow attempted by the Morozov clique might have already been disseminated

44 For the complete text of the account and interesting editorial remarks see Platonov, 'Moskovskie volneniia', pp. 69-75.

45 Bakhrushin, 'Moskovskoe vosstanie 1648 g.'

46 The same pattern can be observed in the large-scale revolts that promoted false tsars. Cf. Maureen Perrie, Pretenders and Popular Monarchism in Early Modern Russia: The False Tsars of the Time of Troubles (Cambridge: Cambridge Univ. Press, 2002).

See Poe, A People Born to Slavery. 
in provincial cities of Muscovy, since it made legal resistance (to Morozov's accomplices) on behalf of the tsar a matter of necessity.

The Chanut-scenario of the Moscow events allows only very general comparisons to the contemporaneous situation in Sweden. Indeed there was widespread resistance against the 'grandees', especially against the overwhelming influence of the Oxenstierna-clan. In Chanut's fantastic account Morozov's people also figure as 'grandees' and not as the social climbers they actually were. In Sweden resistance against the 'grandees' was organised in an oppositional movement assembled around Karl Karlsson Gyllenhielm (1574-1650) and the Count-Palatine Johann Kasimir. It reached into the highest circles of the Privy Council and eventually even included the Queen, where she was trying to emancipate herself from the Chancellor's (Axel Oxenstierna's) paternalism. The opposition's criticism was more or less well-known - due to a series of tracts and leaflets. In 1647 the group had circulated its "Remarks upon the Form of Government", where it castigated "ambition, selfishness, jealousy and ill-will", out of which certain groups "exalt themselves and lord it over the rest". It postulated that the people, "who contribute to the welfare of the kingdom, should know how their money is spent by those who have the handling of it", and that "superfluous officials, and the many foreigners who enter the country and are not essentially necessary to its service, may be struck off, and unnecessary expense spared", since "the revenues are now considerably diminished by reason of the poverty of the people, and because so much crown land has been sold, or granted as fiefs". 48

The pamphlet appeared anonymously, but Gyllenhielm was suspected of being the author. Gyllenhielm's importance for the opposition in Sweden might explain the appearance of the mysterious "Banaanoph" (Bananov) in Chanut's account. Like "Banaanoph" Gyllenhielm was a bastard. "Banaanoph" is presented as a relative of the tsar and the Patriarch's illegitimate son; Gyllenhielm was the illegitimate son of King Charles IX, grandfather of the ruling Queen Christina. "Banaanoph", himself one of the grandees, reveals the treason of his peer group and thus saves the tsar from being assassinated and the Empire from being dismantled. Gyllenhielm and Johann Kasimir, also fight as grandees against their peers' appropriation of state revenues and power and thereby embrace popular resentment in order to rally support, even though they do not openly present the Oxenstiernas and their supporters as conspirators. Most likely in the chain of Chinese whispers about Muscovite events, the whistle-blower "Banaanoph" was an outgrowth of Swedish political expectations and fears.

48 Michael Roberts, Sweden as a Great Power, 1611-1697: Government, Society, Foreign Policy (New York: St. Martin's Press, 1968), pp. 41-42. 
It is particularly interesting that in Chanut's story the Muscovite conspirators would have taken the federalism of the Holy Roman Empire as a model. Was this federalist motive a result of Muscovite or Swedish whispers? In Muscovy the negative idea of the state's fragmentation was related to the 'Tatar yoke'. Therefore it made sense to accuse the alleged plotters of splitting the country, but it would have been more obvious to compare this to the Mongol past. The reference to the Holy Roman Empire as bogey has rather to be attributed to whispering Swedes, who have just seen the devastated German principalities. Indeed, after the Thirty Years' War 'absolutist' aspirations were 'in the air' and federalist tendencies were largely discredited as sources of intestine strife. ${ }^{49}$

\section{The Moscow Uprising in the Gazette de France}

In this last section, I follow the Chinese whispers to Paris, where the Gazette de France 'reports' on the Muscovite events in an Extraordinaire of early October. This is the first account in the chain of communications followed here that was published thereby and addressed a larger audience. The Gazette de France was not a commercial paper run by private entrepreneurs, who were primarily interested in profitmaking, as was the case with most publishers in the Holy Roman Empire. It was a state-run paper, founded only in the previous decade on the initiative of Cardinal Richelieu, who wrote some of the articles himself. The Gazette was therefore, first and foremost, a means of propaganda used by a government with clear-cut absolutist aspirations. Even though the relationship with Cardinal Mazarin was less intimate than it had been with Richelieu, and the Queen's favourite and factual regent hardly ever wrote articles himself anymore, the editor Renaudot and his correspondents remained closely associated with the government. ${ }^{50}$ To judge from the style and the use of metaphors, the article on Muscovy was probably written by Renaudot himself. ${ }^{51}$

In contrast to Chanut in Stockholm, the author of the article had already seen the barricades in Paris in protest against the arrest of the popular

49 On the general aspiration for tranquility see Theodore K. Rabb, The Struggle for Stability in Early Modern Europe (New York: Oxford University Press, 1975).

5o This would only change at the beginning of 1649 , when the French court fled from the capital. Renaudot was with the king and Mazarins in Saint Germain, but Renaudot's sons had remained in the capital and continued to run the Gazette under the influence of the ruling Frondeurs. On the history of the Gazette during the Fronde, see Stéphane Haffemayer, L'information dans la France du XVIIe siècle: la Gazette de Renaudot de 1647 à 1663 (Paris: Champion, 2002).

Ibid., pp. 516-517. 
parliamentarians Broussel and Blancmesnil, as well as Mazarin's surrender and their release after only a few days of imprisonment. It is more difficult to say for sure which items of information and rumours on the Muscovite uprising he used, even more so since he clearly exploited the events in distant Muscovy to transform them into a didactic play for his French readers. He might have known about Chanut's reports. In addition, he had probably read the Leyden Brochure, of which I have found a French manuscript translation in the papers of the (French) court historiographer Denis (II) Godefroy. ${ }^{52}$

The Extraordinaire of the Gazette, dated 8 October 1648, assembles two 'news items' from Eastern Europe. The article on Muscovy is followed by another article on the state of health of Marie-Louise de Gonzaga, Queen of Poland. But the two articles are not related to each other and the assemblage does not mean that the 'news' about Muscovy also came from Poland. Anyway, the author of the account on Muscovy was obviously rather 'creative' with his sources.

The framework of general destruction is described accurately, and also the beginning of the revolt is correctly dated, even if it is given according to the Gregorian instead of the Julian calendar, which was still in use in Orthodox Muscovy and protestant Sweden: "On 12 June in the great city of Moscow broke out a terrible rebellion, during which so many awful things happened that its memory should be rather effaced than refreshed". Interestingly, the report is thus introduced by reference to the imperative of damnatio memoriae. Indeed, the reader learns hardly anything about the events of the revolt. Instead, the account consists almost entirely of the verbal reproduction of an Orthodox priest's sermon that is obviously made up by the author:

But there was a Muscovite clergyman, venerated by for his virtuous life and because he was so zealous in his religion, who managed to tame the rage of the people by his remonstrance. Therefore I thought that it would be a crime to posterity not to report on him. For he reminds us of the greatest histories of Antiquity, where we find important speeches that have been held at numerous occasions, for instance the speech by Menenius Agrippa who saved Rome, and the speech of a peasant from the Danube that astounded the [Roman] Senate. ${ }^{53}$

$5^{2}$ 'Relation véritable du tumulte arrivé en la ville de Mosco, capitale de Moscovie, le 12 Juin 1648', BnF, 'Mélanges historiques sur l'Europe' fol. 287 (La Moscovie, la Perse, la Tartarie), f. $323 \mathrm{r}-323 \mathrm{v}$.

53 'La Harangue d'un callogére ou religieux Moscovite. Sur le sujet des émotions de ce Royaume-là, \& qui se trouvent aujourd'huy presque par tout le monde', Gazette de France no. 154, October 1648, sec. Extraordinaire, pp. 1373-1374. 
Already in this introduction a lot of erudition and many references to antiquity are displayed. The Muscovite clergyman is placed in an illustrious line of tradition. The story of Menenius Agrippa, who went to the insurgent plebeians of Rome and told them the fable of the members' rebellion against the belly and thereby brought them to terms, is well-known from Titus Livy's $A b$ urbe condita (2.32.9). The reference to the Danube peasant has been imputed to Marc Aurel, who attributed the vitiation of morals in Rome to the many flatterers, and in this context would have told the story of one of the very few 'true men' who he met in his life: the story of a simple peasant from the Danube, who came to Rome and forthrightly denounced to the consuls the arbitrariness, abuse of authority and cruelty of the Roman judges in his Province, who heavily suppressed his unhappy people. He mused that the officials had been sent by God to punish and enslave his people for their sins. But during his two weeks in Rome he had seen so much excess and effeminacy that the Romans also seemed to deserve God's punishment and might soon be forced to recognise his people as their masters. For his audacious speech the peasant reckoned with being beheaded. But instead, the Senate replaced all his judges in the province, elevated the peasant to a patrician for his veracity and ordered him to be nourished by the Roman treasury for his entire life. ${ }^{54}$

This is the erudite horizon that is extended before the French readers. As full of references to antiquity as this introduction is, the cleric's speech itself starts with a particular sort of 'audience bashing':

Another one would start by Messieurs: But what do I see around me? To whom should I give the honour and address him with such respect? To those, who have just killed more than 300 people and desecrated the holy places and saints with the blows of their battle axe and their scimitar? To the arsonists [actually: shot firer (boutefeux)], who caused the enormous fire that is still smoldering ...? Would it be our Boyars and main senators [that I might address myself with this respectful address]? - They have lost all credit.... Therefore I prefer to say: miserable people, magistrates, who are no more what you were, masters without servants, slaves without masters, lost flock, spectacle of horror: Rather in order to calm myself and not to remain silent in the face of the destruction of my homeland, and even though the disaster exceeds all possibilities of rhetoric, than for the sake of real hope that I could nourish to figure out a remedy to our evils, do I lament our common misery.

54 A.C.M. Robert (ed.), Fables inédites des XIIe, XIIIe et XIVe siècles: et fables de La Fontaine, rapprochées de celles de tous les auteurs qui avoient, avant lui, traité les mêmes sujets, précédées d'une notice sur les fabulistes (Paris: É. Cabin, 1825), pp. ccviii-ccix. 
Only ruins remain from the old splendor of the biggest city that exists between Asia and the Arctic Sea. Since nobody pities you, pity at least yourselves!55

The orator affirms he has little hope that people will even hear him, since "all the confines of religion have already been offended".

But who listens to me? When I see you running through the streets like madmen, like lions in search of prey, what hope could I nurture? Don't I have to reckon with sacrificing myself then trying to soothe your fury? What do I say? It seems as if our misfortune does not content itself with the damage of our goods and bodies, and still wants to disintegrate our spirits.... Should I hope that those who could be retained neither by the considerations of their wives and children, nor by the honour and decency they had professed during a whole lifetime, might be held off by any other respect once they have trespassed against all limits of religion, honour and contentment?56

Nevertheless, he wants to try to proceed in the manner of a physician, quite similar to Menenius in the fable related by Livy:

However, even though it will be impossible to fight them off, there is still a glimpse of satisfaction, when you at least name the most extreme evils, so that the poor sick can get some relief by sighing at their fate. Although they know that their sickness is about to kill them ..., they often even find some relief when hearing about medicine.... Let's do it in the same way. And to assure myself that at least some of you are listening to me and pausing from their rage, I will imitate the physicians, who use the short intervals of aperture to administer their remedies to the sick. My dear Muscovites, you would have so much reason to calm down. You were so well; and now you have suffered so much from the confusion and disorder and you cannot yet estimate the abysms of misery into which this will precipitate you. ${ }^{57}$

Then he passes on to the Christian faith and the values of charity. He appeals to the submerged moral standards of his listeners:

55 'Harangue d'un callogére', pp. 1374-1375.

$5^{6}$ Ibid., pp. 1365-1366.

57 Ibid., p. 1376. 
Remember that you are humans and Christians ... What is the use of praying to God: forgive us our sins, for we also forgive everyone who sins against us? By seeking revenge isn't it as if you say to God: Condemn us, Lord, punish us in this world and in the other one with all the force and rigour of Your divine justice: and since we are spilling over our next all our wrath, do not spare us from your wrath. Who would not be horrified from such a prayer? And isn't this exactly the message that is emerging from speaking your Sunday prayer in the midst of your chaos and raising your bloody hands to heaven ${ }^{58}$

A considerable part of the sermon asks for the origins of the troubles that could be ascribed "not so much to particular causes but to a general one", in the first place "to ourselves", especially to sinfulness and godless deeds against better knowledge. The preacher recurs to a widespread explanation when referring to the stars, but gives it a particular twist:

Either we attribute [the disaster] to God's wrath that he spills over the whole human race at once, with even more reason since those who carry his name [as Christians] offend him even more than the infidels.... Or [our sufferance has to be attributed] to some influence of the stars, which are used by Divine Justice as a mighty instrument of His vengeance.... It is well-known that common effects have a universal cause. And don't believe that I speak of celestial influence in order to diminish divine power. This is comparable to the actions of Kings that belong to themselves - and even with more splendor and éclat -, when they are carried out by their Council, Sovereign courts or plenipotentiaries, and not by themselves. ${ }^{59}$

This comparison between God as the prime mover, who commands the stars and all their effects on earthly human life, and kings and their state apparatuses as extensions of royal will, illustrates the general amplitude of absolutist desires in the French government. But it has also to be seen in the concrete context of the emergent civil war in France, where the Frondeurs precisely denied that government measures emanated from the young King Louis XIV, who they regarded as Mazarin's hostage.

The alleged Muscovite clergyman situates the uprising not only in a European, but even in a global context.

$58 \quad$ Ibid., pp. 1376-1377.

59 Ibid., pp. 1377-1379. 
And indeed, later centuries will read ... in our history that God's wrath had an effect on the entire face of the earth. Even if the world has rarely been peaceful and the ports of the Temple of Janus could rarely be closed ... the unrest did not easily spread from one climate to another and when one kingdom was at war, another one enjoyed peace. The current protest-movements, though, are not only universal, but they all happen under the same pretext. ${ }^{60}$

The simultaneousness of revolts is seen as a novelty: as an overarching phenomenon that affects "very different climates", a reference to Jean Bodin's theory of climates as determinants of people's temperaments. This accounts for their new destructive power that runs rampant and out of all control:

The three kingdoms of Great Britain have triggered these movements and they are still going on there, Naples has followed them, China had its revolution, Constantinople even before, Germany is divided in factions, Poland armed to the teeth and threatened by enormous divisions [the Gazette had already reported in some detail on the beginnings of the Khlmel'nyc'kyi uprising], Madrid had its part in the tumults, Rome as well: and one has to attribute it to a particular divine protection, when some states have yet been spared or have escaped with mere fear; and here [chez nous, i.e. in Muscovy] things speak for themselves. ${ }^{61}$

The French kingdom is omitted in this list of countries struck by internal strife and civil war. This is no coincidence, but due to damnatio memoriae with regard to revolts at home. The sermon concludes as follows:

Let us admire, my dear Patriots, the secrets of the Almighty: let us seek for the causes of our chaos, uproar and troubles but in ourselves, i.e. in our sins. Instead of putting the blame on each other ..., let us make our peace with God, then we will also find peace ... among us. This will be a veritable confirmation of the word, according to which the wise man has the command of the stars.... And this peace is the true beauty of this life and the reflection of the eternal repose. ${ }^{62}$

According to the final comment of the "correspondent" the sermon did not fail to make a deep impression on the audience:

\footnotetext{
6 Ibid., p. 1378.

61 Ibid.

62 Ibid., pp. 1379-1380.
} 
It was astonishing that all inhabitants of this huge city (of which the stories tell us such miraculous things, for instance that they have a castle, where the grand prince lives, whom they call Tsar and Emperor, and that it can accommodate without difficulty his lifeguard consisting of 20.000 men), after hearing this speech, dropped their battle axes, scimitars and torches, felt ashamed about their former deeds, decided henceforth to do better than before, and resumed their trades and their ordinary business. ${ }^{63}$

Of course, the priest is rather addressing the inhabitants of Paris than those of Moscow. He addresses the 'principal Senators' in Parliament and the 'menu peuple' who had erected barricades. The Moscow uprising is stylised as a model of pacification. This went counter to the habitual othering of the Muscovite Empire as a cradle of barbarism and despotism. ${ }^{64}$ The speech and references are laden with erudition and references to topoi of antiquity. In addition, Moscow appears as part of a European and a global tendency. Even more so, the virtuous return from sin and corruption is presented as a model to the French. The Muscovites are introduced as plain Christians, the Eastern schism is not even mentioned and Orthodoxy thus does not represent a decisive dividing line.

With the invocation of general sinfulness and God's universal punishment all concrete causes are brushed aside. In this way the primacy of damnatio memoriae, announced in the introduction, is consummated: memory of the events and even more so the concrete causes and grievances are 'erased' for the Muscovite uprising. But this is even more true for the Fronde in France that is not mentioned with a single word, even though it is the principle signified of this account that uses the Muscovite uprising as a projection surface in order to comment upon domestic troubles in veiled terms.

Historians tend to ascribe the emergence of what we call 'Aesopian language' to intellectuals in opposition to repressive modern states. The term has been coined in late imperial Russia by authors (namely Saltykov-Shchedrin), who were trying to circumvent censorship. But the practice can be easily traced back historically, ${ }^{65}$ not least to eighteenth-century France, where in

63 Ibid., p. 1380.

64 The negative stereotypes of Muscovy that were widespread in central and Western Europe are summarised for instance in Gabriele Scheidegger, Perverses Abendland - barbarisches Russland: Begegnungen des 16. und 17. Jahrhunderts im Schatten kultureller Missverständnisse (Zürich: Chronos, 1993).

65 Lev Losev, On the Beneficence of Censorship: Aesopian Language in Modern Russian Literature (München: Sagner, 1984). 
Montesquieu's Lettres persanes (1721) and other works it had become a topos to speak about the East in order to implicitly denounce despotism at home. It is not surprising that dissidents recurred to 'Aesopian language' earlier, but it is more noteworthy that they were also - or even initially - used by the authorities in face of domestic strife, since they were afraid to speak plainly.

On the one hand Chinese whispers about uprisings abroad bore considerable danger. Current metaphors and concomitant explicatory patterns suggested that revolts could spread across borders like 'wildfires' or 'epidemics', particularly in the troubled mid-seventeenth century. ${ }^{66}$ Therefore disseminators of unwanted messages were severely punished and often their tongues were cut off. But on the other hand, the spread of rumours could not be defeated by repression, and talk about revolts abroad was considered less offensive than talk about revolt at home. In the present case, therefore, Chinese whispers eventually became a source, from which the French government mixed the ingredients of an Aesopian cocktail designed to provide an Eastern model for the pacification of its own subjects. But this did not prevent the Fronde from unfolding and gaining momentum. Since Mazarin rather despised the relevance of journalism as a means of public persuasion, government propaganda was submerged in a flood of oppositional 'Frondeur' pamphlets that did not tend to mince matters, the so-called Mazarinades. ${ }^{67}$

66 For a broad range of examples for this mid-seventeenth century, see Peter Burke, 'Some Seventeenth-Century Anatomists of Revolution', Storia Della Storiografia, 22 (1992), pp. $23-35$.

67 See Christian Jouhaud, Mazarinades: La Fronde des mots (Paris: Aubier, 1985); Hubert Carrier, La presse de la Fronde (1648-1653): les mazarinades, 2 vols. (Genève: Droz, 1989-1991). 